\title{
Correlation of figurative insight indicators in the experience of future art pedagogues
}

\author{
B. Reinberga*, B. Garjāne** \\ * Daugavpils University \\ ** Riga Teacher Training and Educational Management Academy
}

\begin{abstract}
:
Aim - to reveal the correlations among the indicators of figurative insight for its development. The self-development and self-actualization in the study process that include also the development of figurative insight of future art pedagogues are stressed in this paper.
\end{abstract}

Methods - research on the correlations among the figurative insight using Factor Analysis. The development opportunity is determined by the concepts of personality traits: creativity, self-expression, personal attitude, emotional and intellectual experience. The paper is based on a quasi-experimental research - the communication by future art pedagogues using visual and verbal dominant images in three kinds of exercises.

Results - the indicators determining the figurative insight which correlations encourage the development of figurative insight. Results allow setting a goal to reveal the correlations of figurative insight indicators for its development. According to the aim for the research of the indicators the factor analysis method was chosen. Finally, to determinate validity of the results four criteria were set: openness, flexibility, plasticity and creativity.

Conclusions - in the process of art subject teaching if purposefully working on separate indicators of figurative insight, the overall figurative insight of future art pedagogues can be further developed.

Keywords: figurative insight phenomenon, figurative insight criteria (openness, flexibility) and indicators, figurative insight development

\section{Introduction}

In the aspect of figurative insight the development of creative self-experience rarely conforms to the theoretical knowledge and usage skills. The human comprehension of issues is mainly determined by competition and patterns that in turn endangers one's creative personality and being. Bernard Sordet recognises "The time has come when Le tutorat method regains the importance in education and research. This method states that teacher is a guide in life, spiritual and intellectual support, an adviser and promoter and passes the knowledge through the generations“ (Sordet, 2013). This humanitarian paradigm allows new opportunities to connect the education with spirituality (transcendent) dimensions as well as one's self-development and selfactualization opportunity through the creative processes that include also figurative insight. The personality of a creative pedagogue as well as pedagogical approaches promote self-development, while "in the educational practice figurativeness familiarisation always is more connected to the perception of the art and the analyses of an art work - crafts and handicrafts” (Brikša, 2011, 114-115). In order to advocate the inclusion of the development of figurative insight as a necessity in the study process for future art pedagogues the model of figurative insight (MFI) was created (Reinberga, Garjāne, 2013). The components of the model determine the factors for figurative insight's development. MFI methodological trait is developed according to the iconic principle, when the theory of metaphor is reduced to the linguistic nature of the image. In the metaphor the image is not connected to the sensual images, but depicted in the form of language focused towards the potential experiences of future art pedagogues that can develop their own and student's figurative insight. 


\section{Methods}

Creativity can be further developed throughout the life as the process of spiritual selfexpression and as self-realisation opportunity - "for the person to self-realise and selfexplore in new kinds of artistic acts, opportunity to unleash the individual's creative potential and promote its development" (Grīcs, 1998). It is common when art pedagogues do not connect the knowledge about figurativeness with creative action practice because they believe that figurative insight includes the knowledge that can be defined as "information that is relevant and useful in action, based in experience" (Leonard, 2005). That is the knowledge about figurativeness that has an intangible dimension - the aspects of knowledge that are not articulate, thus the representation of knowledge becomes more and more abstract and the intangible has an opportunity to become more dominant connecting with the sixth sense - intuition. Self-expression shows the direction for thinking and comprehension while searching approaches that helps to centre one's view on self-expression in the language. The holistic content of MFI is targeted towards learning (as individual sphere) correlation with art (as context, subtext sphere) and reveals the opportunity that helps to further develop figurative insight using the images of two arts - literature and visual art. The expression in the self-expression helps the individual to gain new experience in connection with new creative acts.

The linguistic conciseness and inclusive cognitive conciseness are united in significant expression - communication with images in any kind of art, thus when acting on it the figurative insight of respondents can be developed when more attention is paid not on the theory of the art, but on the multidimensionality of the vertical levels of the plural language, (See Figure 1), that determines the insight of figurativeness and indirect meaning, the associative network and fields.

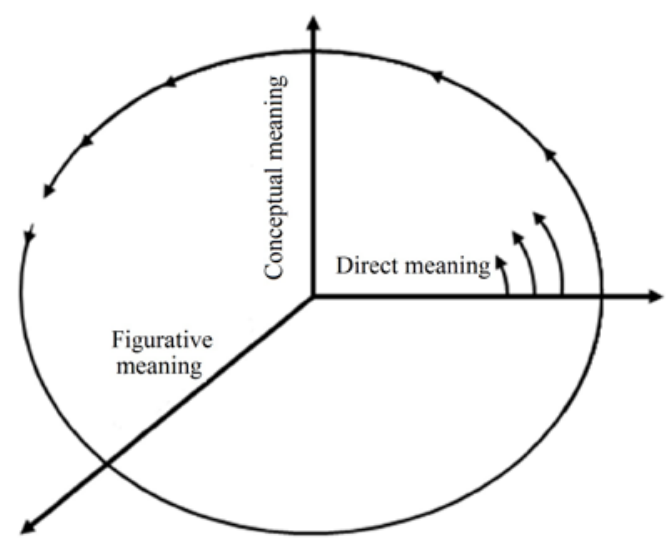

Figure 1. Multidimensionality of word's meaning in regard to criteria (Reinberga, 2009)

The figurative insight that is based in the language and its development is the task of study process (to show that figurative insight can be changed) and the result of study process (recognising certain level of figurative insight). The meaning of the word is a universal medium between the human thinking and notion of the world (Reinberga, 2009). Using the uniqueness of individual's personal figurative insight, with the help of meanings the language can be attributed to all non-linguistic (including figurative insight) phenomenon, this applies also semiotic not only to reality but also to irreality (that metaphorically exists in the images of literature and art), that way becoming universal self-expression in the cognition of the figurativeness, thus semiotic approach can be implemented in the literature and other art sciences. As a result of figurative 
insight the concepts of the creative personality trait in the creative process are determined - creativity, self-expression, personal attitude, emotional and intellectual experience. "These are accepted in order to describe the presence and to gain the understanding” (Gadamer, Ricoeur, 1982). Latvian philosopher M. Kūle, when characterising this process on a deeper level, recognises "the boundaries of thoughts do not come from the outside - from the richness or poorness of the experience that is met by one's mind, but from the inside - from the conceptual force, from the truthfulness of formulated notion that helps the mind to meet the experience." (Kūle, 1989, 110).

Wolfgang Welsch stresses the connection between hermeneutics of art and philosophy - "the art and philosophy must be fundamentally comparable, otherwise there would be a lack of interpretation options that has the compatibility not incompatibility foreseen" (Velšs, 2005, 186-190). "Thanks to the interpretation and its correlate - the understanding, it is possible to move from the material sphere of world's reflection to the subjective sphere of reflection - the perception experience and the insight sphere" (Grīcs, 1998).

Based on the described framework the approach for the interpretation of dominant image approbated in the quasi-experimental research (the communication by future art pedagogues using visual and verbal dominant images in three kinds of exercises) determines the creative environment for the development of figurative insight when the use of a verbal tittle changes the aspect of the repeated dominant image in various exercises, that way the figurative perception and insight are trained in the form of creative multiple variations. The strategy of quasi-experimental research is formed with a goal to compare the results (creative result constructed by subjective imagination and fantasy) of the figurative insight in exercises about two dominant (verbal/visual image) integrative insight using statistically validated six test results. The level of result was categorized according to the levels of MFI (the task of the research is not to unfold the construction process of figurative meanings). Numerical data and the statistical testing of the result using four criteria and their indicators (4 criteria/24 indicators) ensure the validity of the research. MFI and its determined levels of figurative meaning: three didactically various sets of dominant exercises based on the holistic content of an integrated creative action of two subjects. In order to test the validity of the result of dominant exercises four criteria were chosen openness, flexibility, plasticity, creativity (See Figure 2). Openness is an ability to recognise dominant image perceiving the situation offered by the dominant as replicable and as further developable associative content. Flexibility is an ability to move from the given image to another using aspect as a tool of imagination.

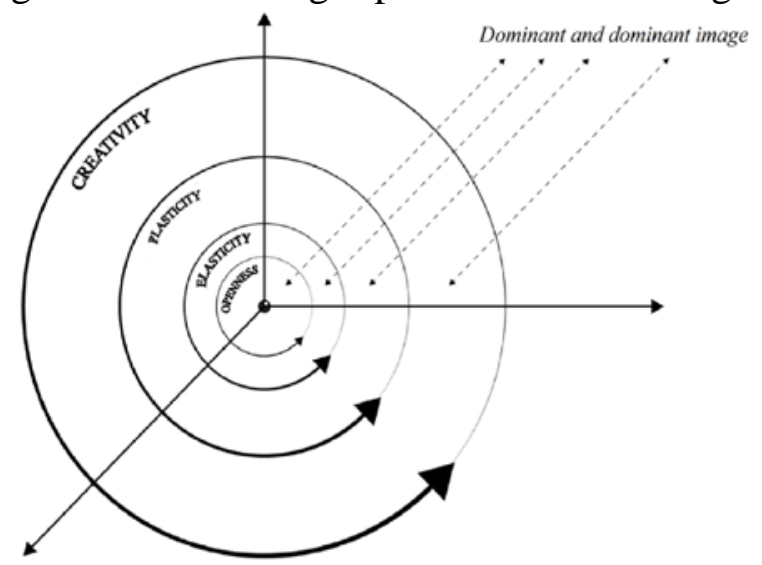

Figure 2. Criteria of figurative insight determined by the dominant (from Brikša, 2011) 
By offering creative process of cognition to the students using the mediation of the dominant, it is tried to determine the opportunity to further develop figurative insight through the previous mentioned factors as purposefully inserted, cognisable, solvable, always potentially further developable. Subjective artistic communication ability is objectively relevant to the existing dominant image; for the visual dominant it is "cognition that is sensitive to visual form elements" (Brikša, 2011, 108), for the verbal dominant, it is the insight of notional and figurative meanings of figurative expression. The interaction of the components forming the interpretation of dominant helps:

- To comprehend complicated relations and attitudes of visual and verbal images,

- To percept and comprehend the figurative meanings offered by dominant,

- To make creative decisions in the level of fantasy in order to form other figurativeness,

- To form other figurativeness text by reforming the former experience of insight to higher level of figurative meaning (Reinberga, Garjāne, 2012).

The future Art, Literature and primary school pedagogues from various universities in Latvia - University of Latvia, Liepaja University, Daugavpils University, Riga Teacher Training and Educational Management Academy - took part in the quasiexperimental research. The main criteria for respondent selection were their affiliation to various higher education institutions, their study programme connection with teaching of art subjects in the future. It was tried to determine if the figurative insight as a part of creative self-expression characterises future art pedagogues (significantly assessing their creativity in the pedagogical practice in the future). The quasiexperimental research allows to:

1) Separate the figurative insight in literature from metaphorisation (figurative expressions of the art science in general);

2) Replicate it in various auditoriums changing the pedagogical means.

The collected data was processed applying statistical methods - according to Cronbach's Alpha test reliability is met only for openness and flexibility because it is impossible to statistically measure creativity, but plasticity is too uncertain category for statistical data inclusion. This paper describes only three significant correlations among the figurative insight indicators. These correlations were determined using Factor Analysis.

\section{Results}

The factor analysis classifying the indicators of figurative insight in levels shows correlation among variables. The correlations explored in the Factor Analysis have pedagogical value that can be implemented in practice in the form of the didactical methods. That way, it puts forefront the opportunities of figurative insight development where interaction between pedagogue and respondent is manifested as a stimulus on one hand and as a certain reaction on the other hand. Matrixes of factor analysis reveal: 1) if students can use figurativeness and its means of expression according to the multidimensional offer of the dominant (7) then it is possible to promote their skill in the creative action to form the images in the figurative meaning (4) and ability to percept the offer of the personal creative action as replicable 
situation (2) as well as ability to recognize the figurative meaning incorporated in a visual image (5) (See Figure 3).

\begin{tabular}{|l|r|}
\hline & Component \\
\cline { 2 - 2 } & 1 \\
\hline 7: Uses figurativeness according to the multidimensional offer of the dominant &, 891 \\
1: Knows figurative means of expression according to the literature theory &, 772 \\
2: Perceives the situation as replicable &, 825 \\
3: Recognises the figurative meaning incorporated in the title &, 740 \\
4: Forms the images in the figurative meaning & \\
5: Recognises the figurative meaning incorporated in a visual image & 6: Chooses the useful for the fantasy \\
8: Perceives figurative contrasts & \\
9: Perceives the dimensionality of images & \\
\hline
\end{tabular}

Extraction Method: Principal Component Analysis.

Rotation Method: Varimax with Kaiser Normalization.

Figure 3. Rotated Component Matrix 1

2) If students know how to use aspect as a method for the imagination (17) then they can verbalise the image of visual dominant in the level of fantasy at a greater capacity (13) and comprehend the symbolic (16) (See Figure 4).

\begin{tabular}{|l|r|}
\hline & Component \\
\cline { 2 - 2 } 17: Uses aspect as a method for imagination &, 909 \\
10: Can unite different phenomenon in the level of fantasy & \\
11: Can interpret the common meaning of 2 visual images & \\
12: Can unite the common meaning of 2 phenomenon &, 858 \\
13: Can verbalise the image of visual dominant in the level of fantasy & \\
14: Senses the subtext &, 889 \\
15: Comprehends the paradox & \\
16: Comprehends the symbolic & \\
\hline
\end{tabular}

Extraction Method: Principal Component Analysis.

Rotation Method: Varimax with Kaiser Normalization.

Figure 4. Rotated Component Matrix 2

3) If students can interpret the common meaning of two visual images (11) then they can also unite the common meaning of two phenomenon (12) and vice versa (See Figure 5).

\begin{tabular}{|l|r|}
\hline & Component \\
\cline { 2 - 2 } 17: Uses aspect as a method for imagination & \\
10: Can unite different phenomenon in the level of fantasy & \\
11: Can interpret the common meaning of 2 visual images &, 980 \\
12: Can unite the common meaning of 2 phenomenon &, 980 \\
13: Can verbalise the image of visual dominant in the level of fantasy & \\
14: Senses the subtext & \\
15: Comprehends the paradox & \\
16: Comprehends the symbolic & \\
\hline
\end{tabular}

Extraction Method: Principal Component Analysis.

Rotation Method: Varimax with Kaiser Normalization.

Figure 5. Rotated Component Matrix 3 


\section{Conclusions}

According to the results of the quasi-experiment the correlations among the separate indicators of figurative insight reveal the receiver's communicative culture with the image of an artwork, one's ability to see the subjective (non-standard) content of dominant, to overcome the habitual, to be ready to synthase the knowledge in creative action. While realizing the emotional comfort through the revelation of new images, students can form their own text based on the perception and insight correlations. In the process of creative self-expression the figurative insight can be further developed pedagogically organising individual's creative self-expression in the direction of the dominant idea, thus forming a dominant images in the level of fantasy.

\section{References}

Briška I, (2011). Topošo skolotāju profesionālo vērtību veidošanās mākslinieciski radošā darbībā. [Development of student teachers professional values in artistic creativity] Rīga, LU, 210 lpp. (in Latvian)

Gīrcs V. (1998). Kultūru interpretācija [Interpretation of Cultures] Rīga; AGB, 11-12. lpp (in Latvian)

Kūle M. (1989). Ceľ̦̌ saprašanas labirintos. [Itinerary in the Labyrinth of Understanding] Rīga. Zinātne, 111 lpp. (in Latvian)

Leonard, D., Swap, W. (2005). Deep Smarts. How to cultivate and transfer enduring business wisdom.Boston, Harvard Business School Press.

Reinberga B.(2009). Verbālā un vizuālā tēla integrācija tēlainās izpratnes pilnveidei pedagogiskajā procesā /DU 51. starptautiskās zinātniskās konferences materiāli. DUAA Saule/ (In Latvian)

Reinberga B., Garjāne B., Reinberga M. (2012). Plenary Lecture Code ID 0132012The philosophy of language in the context of writing - the opportunity to further develop the figurative insight, Creativity in school's curricula with the form of project based learning, Portorož, 18. - 20. April 2012, Slovenia

Reinberga B, Garjāne B. (2013). Integration of the figurative insight with the ecology of personality, Rural Environment. Education. Personality (reep), Jelgava, Latvia

Ricoeur G., Gadamer H. (1982). The conflict of interpretations

Sordē B. (2013). Pārskatīt izglìtību un pētniecību http://www.lsm.lv/lv/raksts/esejas/arpus-etera/bernars-sorde-parskatiit-izgliitiibuun-petnieciibu.a64106/ (In Latvian)

Velšs V. (2005). Estētikas robežcel̦i [Borderline of the Esthetics]. Rīga: Laikmetīgās mākslas centrs. 